Marquette University

e-Publications@Marquette

Social and Cultural Sciences Faculty Research and

Publications

Social and Cultural Sciences, Department of

$1-1-2006$

\title{
The Social Construction of Difference and the Arab American Experience
}

Louise Cainkar

Marquette University, Louise.Cainkar@mu.edu

Published version. Journal of American Ethnic History, Vol. 25, No. 2-3 (Winter-Spring 2006):

243-278. Permalink. (C) 2006 University of Illinois Press. Used with permission. 


\title{
The Social Construction of Difference and the Arab American Experience
}

\author{
LOUISE CAINKAR
}

INTRODUCTION

THEORIES OF IMMIGRANT integration are a tough fit when it comes to Arab Americans. Arabs who migrated to the United States in the first decades of the twentieth century held structural positions and faced barriers of prejudice and discrimination largely similar to those of white ethnics (especially Italians). ${ }^{1}$ Although they were barred from a broad range of institutions run by mainstream whites, they settled in urban and rural areas, ran businesses, worked in factories, built institutions, flourished artistically, held government office in a number of places, achieved a degree of economic success, and led social lives that were intertwined with members of white ethnic groups and often resulted in intermarriage. Of course there are meaningful exceptions to this simplification of history, and in specific localities, for example, the right of Arabs to naturalize was challenged. ${ }^{2}$

Nonetheless, the general profile of the Arab experience in the United States in the early part of the twentieth century displayed more social, political, and economic incorporation than that of racially excluded African Americans, Asians, Native Americans, and Latinos. It also was vastly better than Arab American experiences over the past thirty years, for substantial evidence indicates a widening social distance between Arab Americans and all other Americans. This social distance has been created and reproduced by institutions of power (external to Arab American communities), is measurable, and is manifested in government policies, mainstream cultural representations, public perceptions and attitudes, discriminatory behaviors, physical insecurity, and social and political exclusion. However, there are continuities between Arab communities past and present. In both periods and throughout the intervening years, Arabs have been highly entrepreneurial, heavily engaged in retail trade, and have posted above average median incomes. Indeed, the first wave of Arab immigrants carved out occupational niches and established economic and employment patterns that continue to characterize today's Arab American communities. While from one perspective this economic stability may 
signal success, from another it could suggest blocked socio-economic mobility.

The differences in experience between past and present Arab American generations are due in part to religious factors. The earliest Arab immigrants more often were Christian than Muslim, while the reverse is now the case. But reducing historical changes in the Arab American experience to a Muslim-Christian dichotomy is not as analytically useful as it may appear. Currently, all major American Arab organizations, local and national, are staffed by members of both religious groups and share the same objectives: reducing discrimination, stereotyping, political exclusion, and ethnic vilification. Persons with Arabic-sounding names, whether Christian or Muslim, report experiencing job discrimination and anti-Arab comments, and persons with the "Arab/Middle Eastern" phenotype have been physically attacked regardless of religion. It is not clear that the American public has a differentiated view of the Christian versus the Muslim Arab; the utter simplicity of monolithic, anti-Arab messages has succeeded in precluding thoughtful distinctions. The negative experiences around which Arab American organizations have mobilized preceded by decades the September 11, 2001, attacks but they laid the groundwork for the collective backlash that followed them.

The deterioration in Arab American experiences over time also cannot be explained by economic factors, either of poverty or downward changes in the human capital of Arab immigrants, such as Alejandro Portes and Alex Stepick note with regard to the waves of Cuban immigrants who entered the United States. ${ }^{3}$ The earliest Arab immigrants were predominantly uneducated Lebanese, Syrian, and Palestinian peasants, while since the 1950s Arab immigrants include highly educated Egyptians and Iraqis, predominantly entrepreneurial Jordanians and Yemenis, and better educated Lebanese, Syrians, and Palestinians. In 2000, the proportion of Arabs with high school diplomas and bachelor's degrees was higher than that of the total U.S. population, a figure that applies to every Arab nationality group. ${ }^{4}$ Arab men and women working full-time had higher median incomes in 1999 than did the total U.S. population, a characteristic that applied to all Arab nationality groups except Moroccans and Iraqi and "Arabic" men. At the same time, Arabs had higher poverty rates than did the total U.S. population (17\% versus $12 \%$ ). This difference, however, is explained largely by 1990s Iraqi refugees and to a lesser extent by more recent Palestinian immigrants fleeing continuing deteriorating conditions. While many newer Arab immigrants have low levels of education and job skills, the overall 
social class background and human capital of Arab immigrants certainly has not declined over time.

In the course of ethnographic research in metropolitan Chicago in the 1980s, I found that Palestinians who had migrated to the United States since the 1970s were more intentionally (and overtly) Palestinian than those who migrated before this time, and that cultivating a Palestinian identity was a major life theme for second-generation Palestinians born in the United States in the 1950s and 1960s. ${ }^{6}$ These Palestinian Americans sought to reverse their parents' efforts to shed parts of their history as they achieved economic stability and accommodated to American society. Certainly, the social movements of the 1960s, the influx of new immigrants fresh from Palestine, and the expansion of Palestinian community institutions played a role in this identity formation, but they alone did not provide sufficient cause to loosen one's identification with being American. Rather, global events, the relationship of the U.S. government to them, and accompanying media depictions were more important predictors of the Palestinian American experience than were the viewpoints and customs of new immigrants or post-civil rights American institutional changes, which found Arabs largely excluded from both mainstream organizations and mobilizations of people of color. American media portrayals that have persisted since the 1967 Israeli-Arab War in depicting Palestinians as inherently savage, and the subsequent institutional silencing of Palestinian American and Arab American voices (whether Christian or Muslim), are sociopolitical projects that have fostered the institutional exclusion of Palestinian and Arab Americans and heightened their sense of otherness. Due to global events and the political agendas of powerful institutional actors, the assimilation process, as Richard Alba and Victor Nee recently redefined it, went into reversal as social distance and group distinctiveness became more relevant, not less, for Arab American communities. ${ }^{7}$

These historic achievements, continuities, and reversals of fate highlight the problem of understanding theoretically the Arab American ethnic experience over time. Evidencing neither Gans's theories of straight-line or bumpy social integration over the passage of decades and advent of new generations, nor Portes and Min Zhou's segmented assimilation, nor historic racial exclusion, Arab Americans as a group have experienced a major social shift from the margins of the mainstream to its outer boundaries. ${ }^{8}$ One need only view television and film representations, consult public opinion polls, or spend time among Arab Americans, who strive to lead normal lives in the context of ever-present stereotypes and hostile images, 
to establish their current subaltern position. Negative perceptions of Arabs have been so widely held as to have created measurable harmful impacts on the character of the Arab American experience. At the same time, Arab Americans continue to evidence overall economic success. This seeming incongruity is explained by a combination of factors: the positive economic experiences of the earliest Arab immigrants, who did not face this type of social exclusion nor barriers of color, the high human capital of post-1950s Arab immigrants, the academic achievements of the second generation, and resources embedded in strong ethnic social networks. ${ }^{9}$

The Arab American experience does not fit dominant theories about ethnic integration in the United States because the conditions and variables these theories take into account were developed in earlier historic eras and largely concern domestic matters, while the Arab case is tied to more recent global political developments. Dominant theories do not, for example, consider that domestic institutional processes emerging from American global political interests can have long-term impacts on the social position of ethnic communities. This is perhaps because the negative experiences of Japanese Americans during World War II or German Americans during World War I were quite serious but relatively short-lived (compared to the many more decades-long Arab experience), and the incarceration of Japanese Americans came on the heels of decades of racial exclusion. In other global conflicts, domestic processes have centered on delegitimizing certain political ideologies (e.g., communism, anarchism, liberation theology) and establishing the hegemony of others (e.g., capitalism). Consequently, their social and policy impacts were largely felt by political organizations and activists, while the persons living under the rule of "enemy" ideologies were humanized and offered refuge. But when over a protracted period of time domestic institutions invoke essentialist constructions of human difference as their primary justifications for global political action, backed by power to assert their hegemony, their impact cannot but be felt by the human communities so construed.

The theoretical construction that best captures the Arab American experience over time is racial formation, as elaborated by Michael Omi and Howard Winant. ${ }^{10}$ The structural exclusion of Arab Americans from a wide range of social institutions has evolved from a plethora of "racial projects"-in the media, arts, news, pedagogy, academia, civil society, political organizations, public policy, and popular culture-in which social constructions of the essential differences of Arabs (and later Muslims) have been put forth so extensively as to become widely accepted as common sense, as evidenced in public opinion polls. Winant has argued that 
public policies no longer can be legitimately sold to the public using racial typologies and stereotypes. Alba and Nee argue that the legitimacy of "overtly racist beliefs and practice have never been lower in the eyes of most Americans." ${ }^{11}$ I argue that discourses, with socio-political objectives, that stress essential cultural and civilizational differences are nearly identical replacements for racist ideas and are alive and well in America. ${ }^{12}$

Arab Americans have been racialized using dominant discourses about their inherent violence, which are propped up with confirming images (such as angry mobs) in a process tied to the rise of the United States as a superpower and its foreign (not domestic) policy interests. This stigmatization threw Arab American communities off their previous course in American society as it re-created them as "others," as people who stand in opposition to Americanness because of their inherent values and dispositions. Arab opposition to Israeli military occupation and dispossession was constructed as illegitimate through recreating Arabs as not only violent but also racist and anti-Semitic, another opposition to core American values. Later media fascinations with the question, "can Arabs be democratic?" follow in a similar vein, again positing that Arabs by nature hold values that clash with the essential values of the United States. Widespread American beliefs in the essential social and cultural differences of Arabs erected social boundaries around Arab Americans not of their own creation. Arab Americans conduct their lives in the context of negative representations and discourses, which intensify in parallel to U.S. involvement in the Arab region. With members of the American public they either must engage in reductionist debates about "Arabs" or keep quiet and confine their social relationships to persons who see through these omnipresent images. Arab American civic and political engagement is forestalled by this problematic situation as well as by institutional barriers erected under the pretext that their foreign policy perspectives are illegitimate and un-American. Limited social contact with persons outside of their own group further enhances social isolation. ${ }^{13}$ Institutionally and socially isolated, their communities were easily held collectively responsible for the 9/11 attacks and then transformed into a threat to the nation.

Before turning to the Arab American experience and the process of constructing the Arab other, one final point must be made. In the 1990s, Arab American communities experienced another major shift when increasing numbers of immigrant and second-generation Arab Muslims became engaged in religious practice. While not every Arab Muslim underwent this change, which privileged religiosity over secularism, community-wide transformations in ethos and practice were dramatic and measurable and 
continue to this day. As with earlier shifts in identity and sense of inclusion in American society, this change was not explainable solely by the influence of new immigrants, although they gave momentum to it. Islamic revival was a global process that reached the shores of the United States through Muslim religious leaders, the Internet, satellite television, and return visits to the homeland, as well as through new immigrants. Its appeal to Arab Americans lay in its capacity to provide meaning and resilience for the Arab American experience, a historic role of religion in American life. ${ }^{14}$

In concordance with this global change, essentialized constructions of violent and backwards Arabs were extended nearly seamlessly to Muslims. The same representations were deployed, but instead of being about Arab culture they were about Islam and its "flawed civilization," as expressed in the clash of civilizations discourse popularized by Harvard scholar Samuel Huntington. ${ }^{15}$ As Arab American Muslims became more religious, their differences from others in the communities in which they lived became more pronounced and more real. The evolving paradox, however, is that Muslims, as a religious group, are able to make stronger claims on American civil and political society than Arabs as a racialized ethnic group. The social inclusion of new religious groups in American society, resting on the foundations of freedom of religion, has been much easier to achieve historically than the social inclusion of negatively racialized groups, despite foundational assertions that "all men are created equal."

\section{CONSTRUCTING THE ARAB}

Arabs have had a unique experience with social construction in America. In their one hundred plus year history in the United States, their social status has changed from marginal white to a more subordinate status that shares many features common to the experiences of people of color. Just as one can document and measure the process of becoming white, ${ }^{16}$ a downgrading of the social status of Arabs in America through processes identified as racial formation is measurable: in public policies; mainstream representations; social patterns of discrimination, separation, and exclusion; and in self-identification. While the early Arab American experience (1880-1930) was largely similar to that of white ethnics as measured by residential, employment, and marital patterns as well as land ownership, voting, and naturalization rights (although there are some localized exceptions), the Arab American experience since the late 1960s has been decidedly different. After that moment in time, dominant themes of the 
Arab American experience have been exclusion, prejudice, discrimination, stereotyping, and selective policy enforcement, themes evidenced in scholarly research on Arabs produced during this period. ${ }^{17}$ In the late 1970s, pollsters Seymour Lipset and Martin Schneider found attitudes toward Arabs "close to racist," and in the early 1980s Shelly Slade concluded that "Arabs remain one of the few ethnic groups that can still be slandered with impunity in America." 18

Indeed, the most important, pan-Arab American organizations founded since the 1960s - the Association of Arab American University Graduates, the American Arab Anti-Discrimination Committee (ADC), the Arab American Institute, and the National Association of Arab Americans-had as their primary organizational objectives the reversal of these conditions of inequality and the dismantling of the propositions of innate cultural difference that lay at their root. One of the first historic studies of Arab American communities commissioned by an Arab American organization (ADC) noted:

At a time when the United States is more receptive to cultural pluralism, and ethnicity is no longer socially unacceptable, Arab Americans remain primary targets of defamatory attacks on their cultural and personal character. Thus, much of the activity of the Arab-American community has been directed at correcting the stereotypes that threaten to produce a new wave of anti-Arab racism in the United States and endanger the civil and human rights of the Arab-American community. ${ }^{19}$

The racial formation processes experienced by Arab Americans differ in both historical timing and pretext from that of other groups in the United States. Historically afforded some of the benefits and protections of whiteness, as in their eligibility for homestead lands, legal rights, and voting rights, Arab Americans' exclusion from social and political perquisites post-dates the historic exclusions of other negatively racialized groups. It cannot therefore be perfectly tied, in its genesis, to ideas about race and the superiority of whiteness that have existed since the founding of the United States. Rather, the fall of Arabs from the graces of marginal whiteness is traceable to the emergence of the United States as a global superpower. This socio-political relationship, although not framed in racial terms, is acknowledged in some of the earlier scholarship on Arab Americans. For example, Baha Abu-Laban and Michael Suleiman note that the source of bias against Arabs in the United States relates "more to the original 
homeland and peoples than to the Arab-American community." 20 In the 1984 ADC report noted above, domestic "images of greedy oil sheiks and bloodthirsty terrorists" are tied to political and economic events in the Middle East. ${ }^{21}$ More to the point, "the source of today's defamation of Arab Americans might be described as the domestic counterpart of the ArabIsraeli conflict." 22

Research on Palestinians in the United States showed how maintaining an American identity was fraught with conflict for Palestinian Americans, who were portrayed by the media as a culturally barbaric group, whose organizations were treated by the U.S. government as the enemy within, and whose story of dispossession was framed as a public discourse that was divisive, if not anti-Semitic. ${ }^{23}$ The questions they were forced to ask themselves were: can one be American and America's enemy at the same time? Can one participate in American civil society while being excluded from its discourses? The Palestinian case exposed the racialized nature of the political discourse. Whereas the Soviet, Cuban, and Sandinista enemies were governments and political ideologies, the Arab enemy was Arabs-men and women imbued with innate cultural dispositions to violence and hatred.

The domestic transformation of Arabs from a marginal white to structurally subordinate status was facilitated by the flexibility of whiteness and the historic and "observable" racial liminality of Arabs (a concept that can be extended to South Asians and Latinos). But, at its core, the social and political exclusion of Arabs in the United States has been a racial formation process because Arab inferiority has been constructed and sold to the American public using essentialist constructions of human difference, resulting in specific forms of structural isolation. In the 1990s, when Islamist challenges to American global hegemony became more powerful than Arab nationalism, these constructions were extended more broadly to Muslims and became grander-they became civilizational. Seen as recently as 1943 by the Immigration and Naturalization Service as persons who shared "in the development of our civilization," affirming their whiteness and justifying their eligibility for naturalization, Arabs and Muslims were, by the 1990s, positioned by the "clash of civilizations" viewpoint as the cultural other-a categorization that had become an accepted scholarly perspective. ${ }^{24}$ The seemingly race-neutral lens of essentialized cultural and religious differences became useful after blatant racism had lost its power as an effective hegemonic tool (an outcome of the civil rights movement, according to race scholars). Nonetheless, the components of racialization were there: the assertion of innate characteristics held by 
all members of a group and the use of power to reward, control, and punish based on these determinations.

Since race remains one of the fundamental tools for claiming rewards and organizing discipline in American society-and is something Americans know and understand - these notions of essential human difference have been corporealized, as if they were about color. Thus, race became the operant reference category for a woman voicing opposition to the construction of a mosque in her suburb, when she testified in 2004: "I have no ill remorse for the Muslim race at all. I wish we could all live in peace, but. ..." 25 The corporealization is also evident in the actionable but sloppy phenotypic category "Arabs, Muslims, and persons assumed to be Arabs and Muslims," terms without which no analyst can accurately describe the victims of hate crimes and verbal assault in the United States after the 9/11 attacks. The phenotype became lethal when, one week after terror attacks on London's public transportation, an undocumented Brazilian immigrant was shot dead by London police for wearing a backpack, running into the subway, and "looking Middle Eastern." Similarly, in August 2005 some New York legislators called for baggage checks of persons entering New York subways who fit the "Middle Eastern" profile. ${ }^{26}$

Because the racialization of Arabs is tied to larger American global policies, the domestic aspect of this project is in the manufacture of public consent needed to support, finance, and defend these policies. For this reason, the most noted features of Arab exclusion in the United States are tactical: persistent, negative media representations, denial of political voice, governmental and non-governmental policies targeting their activism, and distortions of Arab and Muslim values, ways of life, and homelands (civilizational distortions). All of these actions are tied to the delegitimation of Arab claims and disenfranchisement of dissenting voices in order to assert an informational hegemony. Arab Americans have maintained their economic successes despite the context of political and social exclusion, in part because they tend to work as professionals and entrepreneurs, in occupations that are largely peripheral to power and the corporate mainstream. ${ }^{27}$

Since the darkening of Arabs began in earnest after the beneficiaries of the U.S. civil rights movement had been determined and the categories of "non-white" and "minority" had been set, Arabs have experienced the double burden of being excluded from the full scope of whiteness and from mainstream recognition as people of color. They are therefore still officially white and ineligible for affirmative action. ${ }^{28}$ As Saliba notes, while Arab Americans have been victims of racist policies, their experiences 
have been rendered invisible by dominant discourses about race. ${ }^{29}$ Their exclusion has been evident in political mobilizations and in multicultural pedagogy. Political exclusion of Arab voices in mainstream civil society has been reinforced by issue-control, through which organizational leaders silence discussion of issues that challenge U.S. policies in the Arab world (e.g., Palestine, Iraq) when assertion of them may frustrate other organizational objectives. In pedagogy, Arabs have been excluded from race and ethnic studies and, when mentioned, are often treated differently from other groups. ${ }^{30}$ Consider the following quote from a race and ethnic studies textbook, which implies that, unlike other groups, Arabs are responsible for their own stereotyping:

Perhaps more serious [than discrimination faced by Muslim women] is the persistence of negative stereotyping that has plagued Middle Easterners in the United States. The activities of Arab terrorists in the Middle East and elsewhere have created a sinister image of Arab and other Middle Eastern groups-an image that was greatly exacerbated by the attack on the World Trade Center in $2001^{31}$ [emphasis added].

The exclusion of Arab Americans and their organizations from mainstream vehicles of dissent also left them with few powerful allies from the 1960s onward (although they have had some measurable local successes), allowing their challenges to hostile media representations, textbook biases, and selective policy enforcement to be ignored without repercussions. ${ }^{32}$ As they stood virtually alone, discrimination and the production of negative images flourished, pointing to the importance of the organizations of civil society for halting racist activities and to the victory of strategies that ensured Arab exclusion from these groups. ${ }^{33}$ Consequently, perpetuation and reinforcement of stigmatized views as well as political isolation left Arabs as open targets for collective punishment after the 9/11 attacks on the United States.

Because the formation of Arabs as a unique "racial" group (separate from whites as well as others) was a process with timing and purpose different from historic American racism, its objective manifestation also differs from that of traditionally subordinated groups: African Americans, Latinos, Asians, and Native Americans. Its impact is not well measured by indices of income, occupation, education, and segregation, because their racialization intervened in the ongoing trajectories of historically successful Arab American communities, and because a large percentage of 
post-World War II Arab immigrants came to the United States with significant amounts of human capital. These facts have allowed Arabs to overcome some of the economic outcomes that usually correlate with subordinate status; at the same time, they mask the deep impact such subordinate status has on Arab communities with low levels of human capital. ${ }^{34}$ For similar historic reasons, some Arabs may see themselves as white (especially if they have benefited or seek to benefit from historical whiteness) while others may not, and Arab American communities may vary in their political alliances and understandings around race. Because of these unusual variations, Arab Americans may have racial optionsa modification of Waters's concept of ethnic options-that members of other groups do not possess. ${ }^{35}$ Nevertheless, these options do not alter their grounded realities as a negatively stigmatized group. ${ }^{36}$ For these reasons of experience and aspiration, a person's racial identity may change over the course of his or her lifetime. For Arab Americans, racialization and racial identity formation should be seen as unfolding and ongoing processes.

The ways in which Arabs, Muslims, and persons assumed to be Arabs and Muslims were held collectively responsible for the 9/11 attacks (demonstrated below) should alone provide convincing evidence that their racial denouement had been sufficiently sealed before the attacks occurred. ${ }^{37}$ The public attribution of collective responsibility for the attacks required an a priori understanding that Arabs and Muslims should be seen as monolithic. This perspective is reserved for persons from cultures represented as backwards or barbaric, where it is assumed that individuals operate in mechanical solidarity "in so far as they have no action of their own, as with the molecules of inorganic bodies. . . In societies where this type of solidarity is highly developed, the individual is not his own master." ${ }^{38}$ Allegations of primitive culture and mechanical solidarity correspond to Western racism as they have been used historically to describe communities of color. Groups described as inherently violent and unassimilable have been held responsible for their own negative fates, not the structures that denied them rights. They have been portrayed as obstacles to the progress of manifest destiny and as the white man's burden.

In contrast, a primary correlate of whiteness is the attribution of modernity, rationality, and individuality, including individual culpability. When someone who is white commits an act interpreted as wrong or reprehensible, it is depicted by the organs of power as an individual act, one that has no reflection on the values and beliefs of other members of the white population. At the same time, paradoxically, the positive virtues of white- 
ness are represented as shared characteristics. Thus, during World War II, Japanese Americans were interned as potential enemies, but neither German Americans nor Italian Americans were so treated. The media spoke of Hitler, Mussolini, and "the Japs." ${ }^{39}$ Hitler and Mussolini's forces were portrayed as deviants and outliers, not reflections on white, European, or Christian culture. But the violent act of any Arab or Muslim is rendered to represent entire societies and cultures, portrayed as a mechanical, civilizational act. As with the Japanese in the United States during World War Two, these racialized ways of thinking require a priori stigmatization and cultural constructions.

Widespread use of the "clash of civilizations" thesis by scholars, filmmakers, publishers, the media, the Christian right, and certain members of the U.S. government-actions similar to what Omi and Winant call racial projects-cemented the social isolation of Arabs and Muslims before 9/11 and established the pre-conditions for collective backlash after the attacks. Since the backlash has been perpetrated largely by whites, it can be seen as a project further defining the boundaries of whiteness. ${ }^{40} \mathrm{Re}$ search conducted in metropolitan Chicago shows that those who perpetrated these acts were often simultaneously displaying American flags, suggesting symbolic attempts to define the boundaries of the American nation and who lies outside of them. While there is no doubt that concerns about personal safety and national security were behind some of the backlash (as well as behind some government policies that followed the 9/11 attacks), it is in their unbridled collective nature, their inclination to target persons who looked like group members, that shows their racialized character. Members of groups that have been "othered" experience collective discipline and punishment, irrespective of any individual's relationship to a particular event, activity, or location.

\section{COLLECTIVE RESPONSIBILITY FOR THE 9/11 ATTACKS AND GOVERNMENT POLICIES THEREAFTER}

Analysis of public policies and data collected in an ethnographic study of the impact of 9/11 on Arabs and Muslims in the Chicago metro area amply demonstrate the imposition of collective responsibility for the attacks on Arab and Muslim American communities, irrespective of the fact that members of them did not plan or perpetrate them. ${ }^{41}$ Arabs and Muslims in the US have experienced, and continue to experience, forms of collective punishment as their looks and names mark them as targets. 
Without much public discussion or debate, the United States government implemented a range of domestic policies in the name of national security and the war on terrorism after the attacks of September 11. Twenty-five of the thirty-seven known government security initiatives implemented between the September 12, 2001, and mid-2003 either explicitly or implicitly targeted U.S. Arabs and Muslims. ${ }^{42}$ These measures included mass arrests, secret and indefinite detentions, prolonged detention of "material witnesses," closed hearings, secret evidence, government eavesdropping on attorney/client conversations, FBI interviews, wiretapping, seizures of property, removals of aliens with technical visa violations, and mandatory special registration. At the very minimum, at least 100,000 Arabs and Muslims living in the United States personally experienced one of these measures. ${ }^{43}$ Furthermore, the number of Arabs and Muslims able to study, work, or attend trainings, meetings, and conferences in the United States has plummeted. ${ }^{44}$ The profiling of Arabs and Muslims at U.S. airports via special security checks and removal from airplanes has dampened their desire to travel domestically or abroad. In a February 2002 article entitled "Flying While Arab," Arab-American Business magazine provided special safety tips for Arab-American travelers. While many Arabs say these selective airport procedures have ended, others remain reticent to fly. ${ }^{45}$

Government measures began directly after the September 11 attacks with the round-up and detention of some 1,200 citizens and non-citizens, most of Arab and South Asian descent. Although the U.S. government has never released identities, profiling based on looks, names, and being in the wrong place at the wrong time characterizes the contexts in which many were arrested and detained. More than five hundred of these detainees were deported for visa violations, after long waits under incarceration for security clearance; none were charged with connections to terrorism. ${ }^{46}$ Subsequent measures included both mandatory holds on all non-immigrant visa applications submitted by men aged 18 to 45 from twenty-six countries (most of them Arab, subject to special security clearances) and interviews with some five thousand individuals who came to the United States from Arab and Muslim countries after January 1, 2000, on non-immigrant visas, plus a second round of interviews with an additional three thousand persons. The Justice Department asked local police departments to participate in interviewing Arab residents of their towns, placing them in the position of monitoring persons they are supposed to protect. 
In January 2002, the INS (now split between two divisions of the Department of Homeland Security) launched an initiative to track down and deport six thousand non-citizen males from (unnamed) "Middle Eastern" countries who had been ordered deported but never left the country. Even though they are less than two percent of the estimated 314,000 so-called "absconders" in the United States, "Middle Easterners" were the government's target. In a meeting with members of Chicago's Arab community, government officials claimed that they were not engaging in racial profiling, since other communities would be approached next, although they never were. ${ }^{47}$ In June 2002, the Department of Justice issued an internal memo to the INS and U.S. Customs requesting that they seek out and search all Yemenis entering the country, including American citizens. Yemeni Americans were removed from planes and boarding lines, waiting hours for security clearances. In July 2002, the INS announced that it would begin enforcing section 265(a) of the Immigration and Nationality Act, which requires all aliens to register changes-of-address within ten days of moving. Nothing prevents the selective enforcement of this rule and, indeed, an INS official from one region openly stated that this rule was not intended to be enforced for everyone. ${ }^{48}$ In North Carolina, a Palestinian legal immigrant stopped for driving four miles over the speed limit was detained for two months and finally charged with a misdemeanor for failing to report his address change. The INS sought his deportation, but a local immigration judge ruled that the defendant could not be deported because he did not willfully break the law.

On August 12, 2002, Attorney General Ashcroft announced the implementation of the Special Registration program, requiring tens of thousands of foreign visitors from Arab and Muslim countries to be fingerprinted, photographed, and registered. The domestic call-in part of the program required non-immigrant ${ }^{49}$ males, aged 16 to 64 , from twentythree Muslim-majority countries, plus heavily Muslim Eritrea (and North Korea), to report and register with the U.S. immigration authorities during a specified time frame in order to be fingerprinted, photographed, and questioned. They were expected thereafter to submit to routine reporting. Credit cards, licenses, and other documents were photocopied and sometimes not returned. Registrants were checked against lists for terrorist connections. Persons cleared of terrorist connections but found to be in violation of their visas or out of (immigration) status were jailed, required to post bond, and issued removal (deportation) orders. ${ }^{50}$

"THIS NOTICE IS FOR YOU" was splayed across the top of INS flyers announcing the registration call-in program, reminiscent of the notices 
posted for Japanese living in Pacific Coast states during World War Two. The arrest and detention in southern California of hundreds of registrants, mostly Iranians, during the first period of registration sparked a national protest, as persons seeking to voluntarily comply with government rules were handcuffed and led off to jail for visa violations. Men in leg shackles were confined to rooms holding fifty or more persons and forced to sleep on concrete floors. Most of these detainees were working taxpayers with families who had otherwise lived lawfully in the United States for decades and many had pending applications for permanent residency. ${ }^{51}$

In May 2003, the government phased out domestic call-in registration. According to the Department of Homeland Security, 82,880 Arabs, Muslims, and others from the selected countries had been "specially" registered through domestic call-in. Of these, 13,434 were issued removal orders for visa violations, all of them affirmatively cleared of terrorism or terrorist connections. Another 127,694 persons were registered at their port-of-entry and none were found to have connections to terrorists. ${ }^{52}$ Of the more than 200,000 Muslims, Arabs, and persons from Muslimmajority countries registered, less than fifty were found to have criminal records. The rounding up for removal of more than 14,000 persons for visa violations-a highly select group comprising less than one percent of the estimated 3.2-3.6 million persons living in the country while "out of status" and the eight million undocumented-has few historic precedents in the United States, far outnumbering the 556 foreign nationals deported for their political beliefs during the infamous 1919 Palmer Raids. ${ }^{53}$

The purpose of the special registration, according to the Executive Associate Commissioner of the INS Office of Field Operations, was to facilitate the "monitoring" of aliens whose residence in the United States warranted it "in the interest of national security." 54 The Department of Homeland Security, which took over the now-divided immigration (and naturalization) functions of the former INS, referred to Special Registration (using its NSEERS acronym) as a "pilot project focusing on a smaller segment of the nonimmigrant alien population deemed to be of risk to national security." 55 These statements make explicit the government's view that Arabs and Muslims as a group are considered a security risk for the United States. This view is found in other Bush Administration programs, such as FBI director Mueller's January 2003 initiative to tie FBI field office goals for wire-tapping and undercover activities to the number of mosques in the field area. ${ }^{56}$

An examination of the legislative history upon which Attorney General Ashcroft legitimated special registration provides useful clues about its 
ideological and racial boundary-making. Ashcroft cited legislative authority for this program encompassing a history going back to the 1798 Alien and Sedition Acts, which were primarily aimed at restraining and deporting aliens living in the United States who were considered subversive. Ashcroft specifically cited as his authority the 1940 Smith Act, formally known as the 1940 Alien Registration Act, which was passed to strengthen national defense in response to fears of communist and anarchist influences in the United States. It required that all aliens over the age of thirteen be fingerprinted and registered, and required parents and legal guardians to register those thirteen years of age and younger. In turn, they received a numbered Alien Registration Receipt Card from the DOJ/INS proving registry and were required to carry this card with them at all times. ${ }^{57}$ The Smith Act was built on 1918 legislation making past and present membership in "proscribed organizations and subversive classes" grounds for exclusion and deportation. The 1918 Act, in turn, was built on the Alien and Sedition Acts of 1798. The Smith Act was aimed not only at foreigners. It also prohibited American citizens from advocating or belonging to groups that advocated or taught the "duty, necessity desirability, or propriety" of overthrowing any level of government by "force or violence." It was the first peacetime federal sedition law since 1798 and was the basis of later prosecutions of persons alleged to be members of communist and socialist parties. The 2002 special registration program thus lies within the family of policies permitting the government to monitor, restrain, and remove persons whose political beliefs and ideologies it perceives as a threat.

On the other hand, because the special registration program named its targets by their country of birth, not their political beliefs, it shares features of the body of U.S. policies based on ideas about race, including slavery, abolished in 1865, and Indian removal. Other such initiatives included the 1790 Naturalization Law, denying naturalized citizenship to non-whites, the last remnants of which were repealed in 1952; the 1882 Chinese Exclusion Act, repealed in 1943; the Asiatic Barred Zone; and the immigration quotas (enacted in 1921 and revised in 1924, 1929, and 1952, whose abolition in 1965 signaled the end of an era in which U.S. immigration policies were based principally on race). Although most of these laws referred to geographies and countries, their explicit purpose was racial. After 1965, it was considered against liberal democratic principles to blatantly discriminate in immigration policies by country of birth. But, in 1981 the regulation of persons from select "foreign states" re-emerged 
in immigration law when the Attorney General was permitted to require "natives of any one or more foreign states, or any class of group thereof" to provide the government with address and other information upon tendays notice. ${ }^{58}$ Interestingly, the Iran Crisis of 1980 was specifically mentioned in the House Judiciary Committee report submitted for the 1981 law, thus connecting new geographically-based immigration policies to political Islam. ${ }^{59}$ Attorney General Ashcroft used the 1981 law to authorize call-in special registration. ${ }^{60}$ Selective policies by country of birth emerged again in 1991 when Attorney General Richard Thornburgh required the special registration of persons holding Iraqi and Kuwaiti passports and travel documents. ${ }^{61}$

In sum, since the end of quotas and the dawn of the civil rights era, punitive or controlling special immigration policies based on country of birth or nationality have been applied solely to persons from (non-European) Muslim-majority countries (with the exception of North Korea) and to Arabs. These place-based discriminatory policies flourish at the nexus of assumptions about the relationship between national origin and presumed inherent cultural and ideological traits-what we have come to label as "race." These laws and policies locate Arabs and Muslims and place them in a subordinate status, thereby reinforcing the appropriateness of maintaining essentialist ideas about members of these groups.

These post-9/11 policies and programs link back to the racialization of Arabs and Muslims because of the essentialized, undifferentiated representations of these groups. Those representations, based on the assumption that persons who inhabit the grand categories of Arab and Muslim possess certain innate characteristics making them a security risk, were institutionalized through homeland security and war-on-terror policies. Operating in tandem with Islamaphobic discourses found in American society, these policies entrench the stigmatization of Arabs and Muslims in the United States. Understanding that race is a historically located social construct that has no fixed meaning and that it differentiates between human beings using discourses of human essences, we must ask: can policies that target persons from two continents, three geographic regions, and through their messiness incorporate persons from three major religions, be considered part of a racial project ? $^{62}$ The answer, I believe, is yes, because they use essentialized categories and understandings to create structural outcomes, which in turn become tied in the public's mind to a phenotype. Thus, a global project that included multiple subordinate populations has been amalgamated into a civilizational racial project. 


\section{POPULAR SUPPORT FOR COLLECTIVE POLICIES}

After the 9/11 attacks, public opinion polls showed broad support for the special treatment of Arabs and Muslims as groups in the United States. A poll conducted in mid-September 2001 found respondents evenly divided over whether all Arabs in the United States, including American citizens, should be required to carry special identity cards. ${ }^{63}$ Two late-September Gallup polls found that a majority of Americans favored profiling of Arabs, including American citizens, and subjecting them to special security checks before boarding planes. ${ }^{64}$ A December 2001 University of Illinois poll found that some 70 percent of Illinois residents were willing to sacrifice their civil rights to fight terrorism, and more than one-quarter of respondents said Arab Americans should surrender more rights than others. ${ }^{65}$ A March 2002 CNN/Gallup/USA Today poll found that nearly 60 percent of Americans favored reducing the number of immigrants from Muslim countries. Five months later, a majority of the American public polled said that there were "too many" immigrants from Arab countries. ${ }^{66}$ In December 2004, a Cornell University study found that nearly 50 percent of respondents in a national poll believed the U.S. government should curtail civil liberties for Muslim Americans. ${ }^{67}$

These polls indicate that the essentialized representations of Arabs and Muslims - propagated by the media and film industry, uncontested in pedagogy, and reflected in government policies and actions-have been extremely effective in garnering public support for treating Arabs and Muslims as a distinct group (often reified in the artificial concept of "Middle Easterners") possessing fewer rights than others. These views would not have emerged so quickly after $9 / 11$ had they not been cultivated prior to the attacks. Otherwise, the hijackers would have been seen in ways similar to Timothy McVeigh, the Oklahoma City bomber, or members of the Irish Republican Army - as extremists whose actions do not reflect on an entire race, religion, or civilization.

\section{ARABS AND RACE FROM THE PERSPECTIVE OF ARAB MUSLIMS IN METROPOLITAN CHICAGO}

Data from interviews conducted between 2002 and 2004 with Arab Muslims in metropolitan Chicago as part of a post 9/11 ethnographic study provide insight into how Arabs view their place in the racial structure of the United States. One hundred and two study participants (see Table 1 for 
TABLE 1

STUDY SAMPLE STATISTICS $(N=102)$

\begin{tabular}{|c|c|c|c|c|c|c|c|c|c|c|}
\hline $\begin{array}{c}\% \\
\text { Female }\end{array}$ & $\begin{array}{c}\% \\
\text { Poor/ } \\
\text { Low } \\
\text { income }\end{array}$ & $\begin{array}{c}\% \\
\text { Middle } \\
\text { Class }\end{array}$ & $\begin{array}{c}\% \\
\text { Upper } \\
\text { Middle } \\
\text { Class \& } \\
\text { Wealthy }\end{array}$ & $\begin{array}{c}\% \\
19-29\end{array}$ & $\begin{array}{c}\% \\
30-49\end{array}$ & $\begin{array}{c}\% \\
\geq \mathbf{5 0}\end{array}$ & $\begin{array}{c}\% \\
\text { H.S. } \\
\text { or } \\
\text { less }\end{array}$ & $\begin{array}{c}\% \\
\text { Some } \\
\text { college } \\
\text { or } \\
\text { BS/BA }\end{array}$ & $\begin{array}{c}\% \\
\text { Post } \\
\text { Grad. }\end{array}$ & $\begin{array}{c}\% \\
\text { Born } \\
\text { US* }\end{array}$ \\
\hline 45 & 18 & 62 & 20 & 30 & 56 & 14 & 14 & 43 & 42 & 29 \\
\hline
\end{tabular}

* Includes for sociological reasons persons who migrated to the US before age 10 .

sample demography) were asked: "There have been discussions about whether Arabs are white or not, with different points of view, do you think Arabs are white, not white, or what?" Sixty-three percent of respondents said Arabs were not white; twenty percent said they were white, while another seventeen percent gave equivocal responses. Study data indicate the elements of social life that persons bring to bear in their assessment of the "racial place" of Arabs, which could be phenotypical, experiential, observational, relational, local, national, or global. These data also point to the complexity of understanding Arab American ideas about race and the need to supplement questions about race using standardized, official categories with questions that take into account the meanings of these terms.

Individuals who said Arabs were not white made this assessment on the basis of, in order of frequency: their treatment in American society; skin color and other phenotypic criteria; the fact that Arabs are multiracial and possess cultural/historical differences from white Europeans; and Arab distinctiveness ("Arabs are Arabs"). Many invoked multiple criteria. A majority of persons who said Arabs are white and about one-third of persons who said Arabs were not white moved immediately into an unprovoked discourse on information and application forms (especially census forms and job and school applications). In other words, the discussion of race became a discussion of boxes, how they respond to these boxes, and the way American society boxes people into groups by color. Arabs know well that they are supposed to check the white box on forms, and a majority say they do so, whether they believe Arabs are white or not and even when they have serious problems with the concept. (Arabs who check "other" and write-in "Arab" or an Arab nationality, or who can be identified as Arabs by language, country of birth, or ancestry, are re-coded by the Census Bureau as white. ${ }^{68}$ 
Q: There have been discussions about whether Arabs are white or not, with different points of view, do you think Arabs are white, not white, or what?

A: This confuses me every time I fill out an application. We are not White, Black, Hispanic, or Asian. We are Arab. I put white. If there is an other, sometimes I put that. But I put White because I know we are not other (Jordan-born female).

Still, some insist on checking the "other" box. This man responded to the question about race as follows:

I always choose “other." I'm not white and I'm not going to check white (Puerto Rican-born male).

A large segment of persons who said Arabs were white said they knew this because it is what they were told.

I was really surprised when I learned that we were Caucasian (US-born woman).

Geographically, Egypt is in Africa but they classify all the Arabs as white, so I write white (Egyptian-born male).

But most make a distinction between what they write on forms and what they see as their reality.

We used to report quarterly on affirmative action and I always asked my boss, "what should I do? Should I put myself as a minority or not?" He did not know either, so we called the company headquarters and they said you will be considered white. But of course in real life we are not. As far as statistics go, that's what they say, legally (Palestinian-born male).

That's one of the things I am thinking about as a student transferring colleges. They have a race question and I have to check white. We are white in this case but in all other cases we are a minority (Palestinian-born male).

Having to check the white box on forms is another form of discrimination to some. 
I am resentful that I have to put down white. I don't look white. I am not treated as white ( 1.5 female).

I don't feel that I am white. I felt I was at a disadvantage to have to check "white." I don't think it's fair because it is not who I am. I just don't feel that I'm a typical white American, you know, Anglo-Saxon, because if you look at me I'm not. I feel that I am a minority. Why should I be grouped with these people and not have a chance to obtain a scholarship? (Libyan-born woman).

Sometimes you put other but what is other? Other could be anything. You feel like inferior, you know. Like the minority of the minorities. We're not defined. . . Officially we are white but we're not white. Somebody can say I don't have to hire you because you are white and I have a lot of white people here. But you're not white! (Palestinian-born male).

\section{Arabs Are Not White: Responses Based on How They Are Treated in American Society}

The largest response category among persons who said Arabs are not white $(36 \%)$ revolved around how Arabs are treated in American society. ${ }^{69}$ In other words, their saw their racial place as non-white because they do not benefit from the statuses, assumptions, and behaviors that accord to whiteness. The overwhelming majority of persons who gave this type of response were born in the United States, suggesting that deep understanding of the relationship between race and inequality of experience are particularly American, formed as part of an American upbringing. These responses, in that they invoke issues that existed before 9/11, support the assertion that racial projects to exclude Arabs from the benefits of whiteness were in place before 9/11.

I call the people I work with white and they ask, "what are you?" What color are we? I don't feel as a white person. People think I must be foreign. People ask me "where are your parents from?" (Chicago-born male).

We have always been told we should be classified as other, then white. But if I go to Mississippi with my brother named Ahmed, there is no way he'd be treated as white (Chicago-born female). 
Arabs are definitely not white. That categorization comes from the treatment of a community by the institutions of American society. Arabs in the schools face the same institutional racism as [do] other students of color (Chicago-born male).

You understand that there is racism even if it is not personally inflicted on you. Being a first-generation Egyptian American and Muslim is a difficult thing-to form an identity of your own and feel like an American and that you fit into this country when you feel you really don't anyway. So, there's always been this sort of racism. ... [T] hat outlook was always there, it was just exaggerated [after 9/11], making you feel like the enemy. That you're the bad one, and you're definitely a foreigner and do not belong in this country. I'm just as much American as anyone else. I feel like maybe I need to get the hell out of this country because something bad is going to happen to our people here (U.S.-born female).

The issue is are you part of a privileged group of people that can dominate others, and I do not think we are part of that. Arabs are not part of the white or European ruling structure. We are politically excluded (U.S.-born female).

Arabs are not white. When I view someone as white they are part of the majority culture. I don't get treated as white, so I am not white. I never check white (U.S.-born male).

\section{Arabs Are Not White: Responses Based on Skin Color and Other Phenotypic Criteria}

The second most common response (28\%) among persons who said Arabs are not white was about skin color and phenotypic features. These responses were found among both U.S.- and non-U.S.-born respondents, although immigrants frequently spoke of how they only learned about ideas and systems organized around skin color after arriving in the United States.

I'm not white, I'm olive. To certain people it matters if you're white (Chicago-born female).

We don't look white. What matters in the U.S. is not Caucasian blood but skin color. This has a huge impact on us. And you see nappy hair, even if blue eyes and light skin (Chicago-born female). 
In this suburb, it is lilly white. We don't belong here. I am very aware of my skin color and looks (Kuwait-born female).

I am from a country that is not white, for sure (Sudan-born male).

You know it's funny, nobody ever discusses color once you step out of the United States. I think it only matters in this country. This country is very race-conscious, color-conscious I mean. My sister married a very dark man and when you look at him you would say he is Black. We never thought that was unusual. . . . I complained about my hair once at school and they said oh, yeh, you have that Semitic hair. I never thought of my hair being Semitic. Sometimes the girls would say to me, "well you are olive skinned." I don't see myself that way. So, I think in their minds they have a perception of gradations of color, and I don't have that (Jordan-born female).

Many respondents were extremely uncomfortable with the very concept of race and color. For a variety of reasons they found it useless, irrelevant, or offensive.

I don't feel comfortable classifying people by color anyway. It is against my ideology, my thinking, and my religion (Egypt-born male).

We are definitely not white. But the whole idea of color makes no sense to me. My neighbor is black according to census forms but she is lighter than I am. There are Arabs that are lighter than white people. I don't think people should be classified like that, by color. I don't agree with it at all. If I was to classify myself, I would consider myself brown. I would not consider myself white. My youngest and oldest child would be white and my middle child brown. It does not work for me (Kuwait-born female).

We do not talk about this issue in our community. We feel that we are Muslims and that is what matters to us (Palestine-born male).

\section{Arabs Are Not White: They Span a Range of Geographic Regions and Skin Colors}

The third most common response (24\%) among persons who said Arabs are not white was that Arabs cannot be a racial group because they encompass many geographic regions and skin colors. 
I think Arabs should have a different category until things change. ... If you look on the map, Arab countries cover two continents and the white white and dark black. If this is my cousin and he's dark, and he's from Africa, are you going to call him white? (U.S.born female).

It does not matter to me because in the Arab community we have white, black, and yellow. As Muslims, there is no difference between colors (Palestine-born male).

Arabs are distinct upon themselves. And the Arab world encompasses both black and white (U.S.-born female).

Arabs are a race of colors, many colors. In my family some have blond hair and blue eyes. Some have brown curly hair. All colors (Lebanon-born male).

\section{Arabs Are Not White: Arab Heritage Is \\ Different from Caucasian/European}

The fourth most common response (20 percent) among persons who said Arabs are not white was about culture and heritage. To them, being white means being Caucasian and European, and Arabs are neither.

Their history and culture is [sic] quite separate from Europe's. I find it a disgrace that the Arab people should be so blatantly insulted by the disregard of their history (U.S.-born female).

I do not think Arabs are white in the sense of Caucasian or white American (U.S.-born female).

White in my mind means European but since I am not European, I feel like I am lying. Why should I write white? (Egyptian-born male).

Most Arabs think Caucasians are Europeans (Kuwaiti-born male).

I have a culture and heritage, being white denies that (U.S.-born male).

The following comments from a young man living in a middle class Chicago suburb show how Arab is counterposed to Caucasian/white/American:

I was with a group of friends. These Americans, Caucasians, drove past us and yelled out remarks — racial remarks. They turned 
around and they ran at us and we started to fight. In Chicago Ridge everyone was Arabic mostly; our whole neighborhood was Arabic ... white person or American would say something about us unless it was in school, but in Orland, it's a little different. Arabic are like, they are not the minorities over there (in Orland Park) (U.S.-born male).

Seventeen percent of respondents gave what may be called equivocal responses to the race question, marking the difficulty they have with the racializing of Arabs as well as the flexible character of the race construct. Along with expressing this ambiguity, the following quote reveals (along with some above) the socially-constructed nature of the way Arabs respond to the formulaic race question and the way it is interpreted through transmitted knowledge.

I don't really know. I think, for me, it's always been white because of what I look like. I consider myself white. That's probably a personal reflection because my skin color is white. I've always thought all Arabs were white. I've never really thought of them as being non-white. But, again, why do we say we're white, because we're not white. Like people say, "you put white," and I think that it just doesn't make sense. I don't know what white means in terms of technical definition. Is it people who live north of the equator? I don't know how the experts have defined it. If you ask anybody, they say to put white as a race. Do I think we're white? I don't think so (Chicago-born female).

\section{THINKING ABOUT THE BOX}

Even though the race question used in the study was not formulated as a discussion of forms and categories, responses nearly always invoked them at some point, signaling both a learned relationship between racial identification and state categories and a deep tension between the Arab experience in the United States and the phenomenon of racial categorization. Nonetheless, when asked whether racial identification matters, thirty percent of persons interviewed said racial position is important in American society, whether they like the concept or not, because it determines benefits. As neither white nor non-white, Arabs accrue neither the benefits of whiteness nor the protections of minority status. They feel this exclusion 
is unfair and further indicates their subordinate status. While quite a few respondents said Arabs should have their own category, like Hispanics, since they do not fit into any existing categories, many think the whole discussion is absurd but for the fact that American institutions work on these premises.

Hmm. Does it matter? It might matter, actually, I'm not really sure. I guess if you're looking theoretical, it shouldn't matter, but when you look on social and political and all that stuff, I think it does matter because of the way institutions in our society run. If you have affirmative action at your university and you're African American, there are rights of having a qualified percentage. We probably wish it doesn't matter, but it does. On resume applications, they look at what your application says. I think it would be foolish to think that they don't look at what your race is (Chicagoborn female).

The formation of Arabs as a unique racial group (distinct from white) was a socio-political process with timing and purpose different from historic American racism, leaving many Arabs in the position of having no racial category (box) that makes sense. Arabs were in the midst of the process that rendered them non-white after the categories of race-White, Black, Hispanic, Asian and Pacific Islander, and Native American-had been set. Arab claims-making over the past few decades for a special category has been declined by the Census Bureau. Although largely rejecting the concept of the racial box, Arabs know that in a racially constructed society thinking inside the box matters.

At the same time, Arab Americans may have racial options that members of other groups do not possess. ${ }^{70}$ When asked, many decide from one context to the next whether they are white or not and whether they will select the box they have been told to select, or think about color and treatment. Their own racial identity may change over their lifetime, based on their experiences, preferences, and demands. Local contexts and organized affiliations may affect Arab American understandings about their racial place. ${ }^{71}$ Racial identity is an unfolding, ongoing, contextual, and socially constructed process for Arab Americans. As the data in our Chicago study suggest, when Arabs select the white box it does not necessarily mean that they identify with whiteness. But when they check other, they know that they have become lost, paradoxically hidden yet the object of social obsession. (They probably do not know that they will be recoded 
as white if they can be identified as Arab.) These options do not alter their grounded reality as a negatively stigmatized group. On the contrary, they offer proof of their racially subordinate status. Thus, the majority of Arab Muslims in the metropolitan Chicago study view their social position in American society as subordinate and translate that status to a non-white racial position in a race-based societal hierarchy. Unfortunately, one cannot conclude from these data if religious affiliation plays any role in this finding since Arab Christians were not part of the study. ${ }^{72}$ It is notable, however, that religion and religious discrimination were rarely invoked in responses to this question, except in statements that Islam does not condone racial distinctions.

\section{DISCRIMINATION AND SAFETY IN THE POST 9/11 ARAB-MUSLIM EXPERIENCE ${ }^{73}$}

Prejudice, discrimination, and a compromised sense of safety are historically correlated with racial subordination in the United States. These experiences have ranged from lynching, mass removals, quarantining, law enforcement profiling, and sentencing disparities to inferior employment, housing, and educational opportunities. Study participants were asked if they had experienced discrimination since 9/11. Fifty-three percent said yes and forty-seven percent said no. Among those who responded "yes," specific instances of discrimination were reported in the following social sectors: employment (39\%), public space (22\%), schools (11\%), law enforcement (11\%), commercial transactions (9\%), government offices $(9 \%)$, airports/airplanes (7\%), and civil society institutions (6\%). These responses are related to a specific interpretation of the meaning of the term discrimination, which is to be denied something or treated in a different way than others. Many respondents did not interpret hate speech or being watched while conducting routine activities, such as loading their trunks, as discrimination. The same applies to feeling unsafe or fearing removal from the United States, which came up in many interviews in the context of other questions.

Some respondents changed their daily life patterns to avoid placing themselves in situations in which they expected to experience discrimination. Quite a few interviewees spoke of eating separately and changing job positions, friendship groups, or their names as means of avoiding verbal harassment or abuse. Many persons who used to travel domestically have altered their travel patterns after the attacks; they either stopped traveling or drove to their destinations. These actions indicate that the policing 
and control of members of the group has moved inside the mind of the individual, what Hatem Bazian and Nadine Naber call "virtual policing." The overwhelming majority of our interviewees reported being verbally insulted, although these events took different forms depending upon the context in which they occurred. Insults were reported in public spaces, in the schools, in the context of commercial transactions, and in shopping malls. Many reported negative comments at work or in the process of applying for jobs. Some reported attacks on their homes, and a number of women were spit upon. "Go back to your country" was the most frequent slogan in public attacks, followed by "we want to kill you." Comments about Arab terrorists were common in work-related slurs.

Despite the fact that many interviewees said they had not experienced discrimination, the overwhelming majority said that there are places in American society in which they do not feel safe. Feelings of lack of safety in public spaces appear to be gendered, as women, especially muhajibaat (veiled women), express this feeling more than men. Suburban shopping centers and malls were mentioned frequently as places where women endured stares and insults. Feeling unsafe is not limited to the public sphere. The government's use of secret evidence, closed hearings, interrogations, and home invasions appears discriminatory to members of Arab and Muslim communities. Consequently, many of them feel vulnerable to a certain degree, even in their own homes. Thus, while some persons in the study said they felt safest in their homes, others said they felt the hidden eyes of surveillance, assumed their phones were tapped and computers monitored, and were concerned about the right of government agents to enter their homes at any time without having permission or leaving a trace. Such matters of collective safety and security historically are tied to racial subordination in American society. The circle of closure that Arabs and Muslims feel is not physically tangible, but many fear it could become so if another attack occurs. Most persons interviewed for this study report that they do not feel secure in the United States, and many expressed fears of mass deportation, revocation of citizenship, or internment camps. ${ }^{74}$ Those with resources have adopted strategies to anticipate these potential outcomes: they have sent their children to universities in other countries and begun building homes in their countries of origin.

This feeling of "homeland insecurity" is exacerbated by the post 9/11 increase in discourses about civilizational differences between Arabs/ Muslims and persons holding Western values. These ideas are broadcast and published in mainstream American media, particularly by neoconservatives and Christian-right spokespersons, and are used to justify a range 
of government actions. Some of these spokespersons have described Islam as a religion outside the pale of human values and Muslims as "worse than Nazis." 75 A booklet entitled Why Islam is a Threat to America and The West argues that Muslims are a fifth column in the United States and "should be encouraged to leave" the country. ${ }^{76}$ Televangelist Pat Robertson called Muslims potential killers on his $700 \mathrm{Club}$ program. ${ }^{77}$ While in office, former Attorney General Ashcroft stated in an interview with syndicated columnist Cal Thomas, "Islam is a religion in which God requires you to send your son to die for him. Christianity is a faith in which God sends his son to die for you." 78 Indeed, Arabs and Muslims feel quite uneasy about the close alliance between the Bush Administration and the Christian Right.

\section{CONCLUSION}

The racial formation processes experienced by Arab Americans differ in both historical timing and pretext from that of other groups in the United States. Unlike the historical argument of racial superiority and inferiority used to buttress the development of the United States as a country of white privilege, the fall of Arabs from the grace of marginal whiteness is traceable to the later emergence of the United States as a global superpower. The seemingly race-neutral lens of essentialized cultural differences and innate violence was promoted in the media and left to percolate by the educational system, thereby building support for government policies that targeted Arab Americans, justifying their political exclusion. This approach was effective and powerful because, while it buttressed U.S. global policies, it did not appear blatantly racist.

Racial projects that moved Arabs into subordinate status began to clearly mark the Arab American experience in the late 1960s and provided momentum for the foundation of pan-Arab American activist organizations. In the 1990s, when Islamist challenges to American global hegemony became more powerful than Arab nationalism, these essentialized constructions were extended to Muslims and became grander; they became civilizational: Both Arabs and Muslims were represented as persons of inherently different values and dispositions than "Americans." These constructions became racialized since race is a key category for organizing difference in the United States and is something Americans know and understand. It is an interpretive construct with great power in American society and one that newcomers quickly learn. Like others, Arabs are informed as to what their official racial group is, but, unlike others, many Arabs find a disjuncture 
between their category (white) and their experiences, since race is understood as a phenomenon with experiential correlates.

For decades, Arabs in the United States have faced challenges from the public over their beliefs, values, opinions, and culture. Their protests over negative representations have been silenced by their powerlessness, an outcome of their blocked participation in the institutions of civil society. The corporealization of the essentialized Arab/Muslim, embodied in images of dark haired, olive-skinned, and hook-nosed persons, came to life as "Arabs, Muslims, and persons assumed to be Arabs and Muslims" faced widespread attack after $9 / 11$. Notions of collective, civilizational responsibility justified imputing to Arabs and Muslims a collective guilt for the attacks. As persons purportedly of a different civilization, Arabs/Muslims were counterposed to Americans and to whites-they were suspected, unsafe, and virtually circled.

The most noted features of Arab exclusion have been persistent, negative media representations, denial of political voice, governmental and non-governmental policies that target their activism, and civilizational distortions of Arab and Muslim values and ways of life. Since the darkening of Arabs began in earnest after the beneficiaries of the U.S. civil rights movement had been determined and the categories of "non-white" and "minority" had been set, Arabs have experienced the double burden of being excluded from whiteness and from mainstream recognition as people of color. Their isolation from mainstream vehicles of dissent left them with few powerful allies to contest their treatment in American society, leaving them open targets for collective punishment after the 9/11 attacks on the United States. While many Arab American activists recognized long ago that the road to their political inclusion and an end to the discrimination was in alliances with people of color, their untouchable issues (especially, Israeli military occupation of Palestinian lands) and their domestic economic role as urban shopkeepers placed strains on these relationships. Perhaps one of the positive developments in the post 9/11 America is the greater willingness of these groups to accept Arabs into their ranks.

Viewed over its one-hundred-year history, the Arab American experience is not well explained by prominent theories of immigrant integration and ethnic assimilation. The reason for this lies in a number of assumptions: that race is a special case of ethnicity rather than a discredited but still powerful social organizing tool; that the creation of racially defined subordinate groups is a legacy of the American past (although the consequences of this history endure); and that no new racial groups will be constructed. It follows from these assumptions that no new group will 
experience downward movement on the color line, because in post-civil rights American society racial projects asserting the essential human difference of certain groups are no longer acceptable. Those days are over. Research should therefore focus on whether the color lines are blurring, whether some groups are permeating the old boundaries of race as evidenced by upward mobility, and whether some groups continue to face racially-based subordination.

I have shown that racializing processes are not just legacies of the American past, that racist ideas composed of social constructions of essential human differences can be effectively hidden behind new discourses, and that government policies may even promote these ideas. The fact that such policies are rooted in global matters instead of the domestic distribution of power and resources does not alter the fact that they produce domestic inequality, civic and political exclusion, pedagogical stereotyping, and that they incite hate crimes, prejudice, and discrimination. Arab American experiences with these social phenomena affect how they see their place in the American racial order. Many Arab Americans have been critical of American democracy because of their very real experiences of political exclusion with regard to challenging U.S. foreign policies, civic exclusion because their issues are portrayed as "divisive," and the use of stereotypes and hostile images to support government policies. These aspects of the American political system are well known in the Arab world, affecting - in the views of many Arabs - the sincerity of American efforts to install democracy around the world.

The one-hundred-year history of Arab American communities provides clarity to this analysis, since one can compare their experiences before and after negative racialization. Arab Americans were at one time considered white, although this status was contested in some locations, and they largely benefited from marginal whiteness during the first decades of their American experience. After they were constructed as a group at odds with American values, as inherently violent and oppressive, they lost privileges in many American social and political realms. The spread of Islamic revivalism to the United States offered resources to dispirited Arab American Muslims: hope, a way of life based on a belief in God, and social relationships that offered dignity, inspiration, and strength. ${ }^{79}$ The capacity of religion to provide "refuge, respectability, and resources" is well recognized. ${ }^{80}$ Unfortunately, as the Islamic revival spread across the country, so, too, were ideas about Arab barbarism extended to Muslims and evolved into a discourse of inherent civilizational differences. As the paradigm and phenotype were extended to Muslims, Arab and Muslim were conflated, 
making it is necessary to speak about them in one construct: the Arab/ Muslim/Middle Easterner. This consolidation will move Arab and Muslim Americans into a new trajectory that may begin to transform dominant discourses, because Muslims as a religious group may be more successful making claims on American institutions than racially subordinated Arabs, a pattern borne out in the history of race and religion in the United States.

\section{NOTES}

1. Early Arab immigrants largely fit into the Not-Quite-White category, which includes Italians, Poles, Slavs, Jews, and Greeks, among others. This conclusion is based on an analysis of the structural position of Arabs demonstrated in the published literature on the early Arab immigrant experience (1890-1930). I consider the legal rights (such as property ownership, voting, immigration, and naturalization), residential patterns, and employment experiences of Arab immigrants and their children as primary indicators of their marginal white social status.

2. There is evidence that in some locations, such as Detroit, Buffalo, and parts of the South, their marginal whiteness was contested. This outcome corresponds to the notion that racial projects can have distinct local characteristics within the context of larger national structures. An examination of the racial status and positioning of the early Syrian immigrants is found in Sarah Gualtieri's work. See, for example, Sarah Gualtieri, "Strange Fruit? Syrian Immigrants, Extralegal Violence and Racial Formation in the Jim Crow South," Arab Studies Quarterly 26 no. 3 (2004): 63-85.

3. Alejandro Portes and Alex Stepick, City on the Edge: The Transformation of Miami (Berkeley, CA, 1993).

4. United States Department of Commerce, U.S. Census Bureau, We the People of Arab Ancestry in the United States (Washington, DC, March 2005).

5. Ibid. "Arabic" corresponds to persons who described their ethnicity as Arab, Arabian, or Arabic and is different from the collective Arab category. Analysis of census data for metropolitan Chicago showed that, among Arabs, Palestinians were most likely to use this term.

6. Louise Cainkar, "Coping with Culture, Change, and Alienation: The Life Experiences of Palestinian Women in the United States" (Ph.D. diss. Northwestern University, 1988). By "intentionally Palestinian," I mean that they defined much of their everyday cultural and political activity in reference to a specific Palestinian identity.

7. Richard Alba and Victor Nee, Remaking the American Mainstream: Assimilation and Contemporary Immigration (Cambridge, MA, 2003).

8. Herbert Gans, "Introduction," in Neil Sandburg, Ethnic Identity and Assimilation: The Polish Community (New York, 1973): vii-xii; and Alejandro Portes and Min Zhou, "The New Second Generation: Segmented Assimilation and Its Variants," Annals of the American Academy of Political and Social Sciences 530 (November 1993): 74-96. The characteristics of those experiencing Portes and Zhou's incorporation as disadvantaged minorities are becoming evident among Arabs of low socio-economic status in Chicago. This phenomenon has developed in the past fifteen years. For racial exclusion, see for example, Robert Blauner, Racial Oppression in America (New York, 1972).

9. An examination of the role of social capital (ethnic and religious) and occupational niches in maintaining the economic success of Arab Americans despite other negative changes is warranted. The author has proposed such a study. 
10. Michael Omi and Howard Winant, Racial Formation in the United States: From the 1960s to the 1990s (New York, 1994).

11. Howard Winant, The World is a Ghetto (New York, 2001); and Richard Alba and Victor Nee, Remaking the Mainstream, 15.

12. It is certainly meaningful that the editors of Contexts, a publication of the American Sociological Association, included this discussion in the Fall 2005 special issue on race. Louise Cainkar, "Violence Unveiled," Contexts 4, no. 4 (Washington, DC: American Sociological Association), 67. My argument that Arab Americans have been racialized builds on Naber's by locating its source, as well as the source of Arab American invisibility and the "racialization of Islam," in structural foreign policy interests. See Nadine Naber, "Ambiguous Insiders: an investigation of Arab-American invisibility," Ethnic and Racial Studies 23, no. 2 (2000): 37-61.

13. Exceptions to this pattern are found among activists and others linked to progressive organizations and low-income Arabs in multi-racial neighborhoods, where dominant stereotypes have less credibility.

14. I discuss the process of Islamic revival among Arab Americans extensively in another paper. See Louise Cainkar, "Islamic Revival Among Second-generation Arab Muslims in Chicago: The American Experience and Globalization Intersect," Bulletin of the Royal Institute for Inter-Faith Studies 6, no. 2 (Autumn/Winter, 2004): 99-120.

15. Samuel Huntington, The Clash of Civilizations and the Remaking of World Order (New York, 1996).

16. For the process of becoming white see David, Roedigger, The Wages of Whiteness: Race and the Making of the American Working Class (New York, 1991); and Noel Ignatiev, How the Irish Became White (New York, 1995).

17. See, for example, Jack Shaheen, The TV Arab (Bowling Green, OH, 1984); Shaheen, Reel Bad Arabs: How Hollywood Vilifies a People (New York, 2001); Michael W. Suleiman, ed., Arabs in America: Building a New Future (Philadelphia, 1999); Ernest McCarus, ed., The Development of Arab American Identity (Ann Arbor, MI, 1994); Sameer Y. Abraham and Nabeel Abraham, eds., Arabs in the New World: Studies on ArabAmerican Communities (Detroit, 1983); Baha Abu-Laban and Michael Suleiman, eds., Arab Americans: Continuity and Change (Belmont, MA, 1989); M. Cherif Bassiouni, ed., The Civil Rights of Arab-Americans: The Special Measures (North Dartmouth, NH, 1974); Louise Cainkar, "Coping with Culture," 1988; James Zogby, Taking Root Bearing Fruit (Washington, DC, 1984).

18. Ronald Stockton, "Ethnic Archetypes and the Arab Image," in The Development of Arab American Identity, ed. Ernest McCarus (Ann Arbor, MI, 1994), 119-53; Seymour Martin Lipset and William Schneider, "Carter vs. Israel: What the Polls Reveal" Commentary 64, no. 5 (1977): 22; and Shelly Slade, "Image of the Arab in America: Analysis of a Poll on American Attitudes," Middle East Journal 35 no. 2 (Spring 1981): 143.

19. James Zogby, Taking Root, 1984, 21.

20. Abu-Laban and Suleiman, Arab Americans, 1989, 5.

21. Ibid., $18,21$.

22. Ibid., 22.

23. Louise Cainkar, "Coping with Culture."

24. U.S. Department of Justice, Immigration and Naturalization Service, "The Eligibility of Arabs to Naturalization," INS Monthly Review 1 (1943): 15.

25. Field data, Orland Park mosque hearing. April 2004.

26. "Middle Eastern" is an artificial construct created in the West with varying definitions. For some, the Middle East ranges from North Africa through Muslim South Asia. For others, it is the Arab countries in Asia. Sometimes its geographic area is left undefined. Very few persons from "Middle Eastern" countries identify with the term. In Census 2000, 
2.4 percent of Arab respondents gave their ethnicity as Middle Eastern. See U.S. Census Bureau The Arab Population (Washington, DC, 2003): 2.

27. The author examines this proposition about the relationship between income, occupational niches, and the social and political exclusion of Arabs and Muslims in current work in progress.

28. Helen Hatab Samhan, "Not Quite White: Race Classification and the ArabAmerican experience," in Suleiman, Arabs in America: Building a New Future (Philadelphia, 1999), 209-26.

29. Therese Saliba, "Resisting Invisibility," in Suleiman, Arabs in America, 304-19.

30. Louise Cainkar, "The Treatment of Arabs and Muslims in Race and Ethnic Studies Textbooks," paper presented at the Annual Meeting of the American Sociological Association, Atlanta, Georgia, 2002.

31. Martin Marger, Race and Ethnic Relations (Belmont, CA, 2003), 165. Emphasis added.

32. See Fay in Zogby, Taking Root, 23, where she discusses the isolation of Arab Americans and ADC's efforts to establish ties with other ethnic and racial groups in order to forge anti-racist alliances.

33. Indeed, this exclusion is invisible to many, rendering attributions of Arab blame for their own situation plausible, the very outcome desired by the crafters of stereotypes and strategies of exclusion.

34. Here we may see evidence of segmented assimilation processes.

35. Mary C. Waters, Ethnic Options (Berkeley, CA, 1990).

36. In other words, I argue that subjective matters of Arab American identity, including racial identification, and Arab American political alliances should be examined as outcomes of the structural processes I describe. They are not independent of these processes nor can they be used to explain the structural position of Arab Americans.

37. I am speaking domestically here, but the wars in Iraq and Afghanistan and other features of the War on Terror (Guantanamo, torture, rendering, disappearances) suggest a collective global responsibility.

38. Emile Durkheim, in Anthony Giddens, ed., Emile Durkheim: Selected Writings (London, 1972), 139.

39. Elliott Barkan provided this nugget of media history.

40. See Louise Cainkar, "The Impact of $9 / 11$ on Muslims and Arabs in the United States," in The Maze of Fear: Security \& Migration After September 11th, ed. John Tirman (New York, 2004), 215-39; and Louise Cainkar, Homeland Insecurity: The Arab/Muslim American Experience after 9/11 (New York, forthcoming), working title.

41. The study was funded by a grant from the Russell Sage Foundation.

42. Fred Tsao and Rhoda Rae Gutierrez, Losing Ground (Chicago, 2003).

43. Some 83,000 persons living in the United States underwent call-in special registration, according to the Department of Homeland Security. At minimum, at least 20,000 additional Arabs and Muslims nationwide have been affected by one or more of the numerous post-9/11 national security initiatives.

44. See chart in Louise Cainkar, "Global Impacts of the September 11th Attacks" Journal of Comparative Studies of Africa, Asia, and the Middle East" 24, no. 1 (Winter 2004): 248.

45. Data from ethnographic study.

46. United States Department of Justice, Office of the Inspector General, The September 11 Detainees (Washington, DC, 2004).

47. Statement made at a meeting with top regional government officials and members of Chicago's Arab community.

48. National Immigration Forum, national conference call, August 15, 2002. 
49. "Non-immigrant aliens" includes all immigrants who are inspected by the INS upon entry to the United States and are not U.S. citizens, permanent residents, applicants for permanent residency, refugees, or applicants for asylum. Special registration excluded non-immigrants who are diplomats, persons working with international organizations, and a few other narrow categories of non-immigrants (categories A and G).

50. Richard Swarms, "More than 13,000 May Face Deportation," New York Times, 7 June 2003; Reuters, 18 December 2002; BBC News Online 19 December 2002; Newsday 13 December 2002.

51. Reuters, 18 December 2002.

52. Carol Hallstrom, Department of Homeland Security, Community Relations, Chicago, e-mail to Louise Cainkar, June 2003.

53. 556 foreign nationals were deported during the Palmer Raids. Alex Gourevitch, "Detention Disorder," The American Prospect Online, 31 January 2003. Operation Wetback is another instance of mass expulsion.

54. INS Memo (undated), HQINS 70/28, from Johnny Williams, Executive Associate Commissioner, Office of Field Operations.

55. U.S. Department of Homeland Security, "Fact Sheet: US-VISIT Program, 19 May 2003. The acronym NSEERS stands for National Security Entry Exit Registration System.

56. See, e.g., Michael Isikoff, "The FBI Says, Count the Mosques," Newsweek, 3 February 2003. For a list of some of the earlier programs, see Louise Cainkar, "No Longer Invisible: Arab and Muslim Exclusion After September 11," Middle East Report (Washington DC: MERIP), No. 224 (Fall 2002), http://www.merip.org/mer/mer224/224_ cainkar.html.

57. The law requiring aliens to carry their registration documents with them at all times is still on the books. This would mean that carrying one's passport bearing registration information is mandatory, although not currently enforced.

58. Public Law, 97-116, December 29, 1981, Immigration and Nationality Act Amendments of 1981.

59. House Judiciary Committee, Report No. 97-264, 2 October 1981, "Need for Legislation."

60. 67 Federal Register 52584 (8 December 2002).

61. 56 FR 1566. This registry was during the 1990-91 Gulf War period. The government's stated reasons for registry include the Iraqi theft of Kuwaiti travel documents, the "potential for anti-U.S. terrorist-type activities" because of "US condemnation of and economic sanctions against the Iraqi invasion of Kuwait," and "securing information on terrorists." Reno rescinded this rule in December 1993, amended the Code of Federal Regulations to make the country designation process simpler, and then published a Federal Register notice requiring "certain nonimmigrants from Iraq and the Sudan" to register. In 1996 Reno added "certain nonimmigrants bearing Iranian and Libyan travel documents. Ashcroft added Syria to this list on September 6, 2002, and at that time declared that citizens and nationals of these five countries, and persons believed to be such, were subject to the newly expanded special registration.

62. Omi and Winant, Racial Formation, 1994, 71, define essentialist as a "belief in real, true human essences, existing outside or impervious to social and historical context."

63. Daniel Smith, "When 'For a While' Becomes Forever," Weekly Defense Monitor, 2 October 2001.

64. Chicago Sun-Times, 2 October 2001.

65. The News Sun (Springfield, IL), 20 December 2001.

66. Gallup News Service, 8 August 2002.

67. Erik C. Nisbet and James Shanahan, Restrictions on Civil Liberties, Views of Islam, \& Muslim Americans (Ithaca, NY, 2004). 
68. U.S. Department of Commerce, Census Bureau, Technical Documentation, Summary File 3, 2000, issued March 2005. There was a popular movement among many Arabs in the United States to check the "other" box and write in Arab as an expression of nonwhiteness and to push for an Arab category. This effort was largely undone through recoding. A few Arab nationalities are curiously exempt from the white re-code.

69. Since these are open-ended ethnographic interviews, some persons offered responses that fall into multiple categories.

70. Mary Waters developed the concept of "Ethnic Options." I am extending this concept to race. See Waters, Ethnic Options.

71. The quite different responses to the race question in the Detroit Arab-American Survey may be the result of a number of factors, primary among them local Arab American experiences with race and with political organizing, as well as methodological. The question was formulated in a manner that replicated official categories and boxes. See Wayne Baker, et al., Preliminary Findings from the Detroit Arab American Study (Ann Arbor, MI, 2004).

72. Read finds some evidence that Muslims experienced more discrimination after 9/11 and that they were more likely to define and perceive themselves as a minority group than Christian Arabs. See Jen'nan Ghazal Read, "Multiple Identities and Post 9/11 Discrimination: A Comparison of Muslim and Christian Arab Americans," in From Invisible Citizens to Visible Subjects: "Race" and Arab Americans Before and after September 11th, ed. Amaney Jamal and Nadine Naber (Syracuse, NY, forthcoming).

73. A more extensive elaboration of this section may be found in Louise Cainkar, "Thinking Outside the Box: Arabs and Race in the U.S.," forthcoming in Amaney Jamal and Nadine Naber, eds., From Invisible Citizens to Visible Subjects.

74. These fears may be receding, as long as the domestic front is quiet. Fears remain about what might occur in the event of another terrorist attack.

75. Mathew Lee, "US Evangelist says Muslims 'Worse Than Nazis'," Agence France Press 12 November 2002.

76. William Lind and Paul Weyrich, Why Islam is a Threat to America and the West (Washington, DC, 2002).

77. Mohamed Nimer, "Muslims in America After 9-11," Journal of Islamic Law and Culture 7 no. 2 (2003): 73-101.

78. Ibid. For more documentation of these types of comments, see American Arab Anti-Discrimination Committee, Report on Hate Crimes and Discrimination against Arab Americans: The Post September 11 Backlash (Washington, DC, 2003).

79. The spread of Islamic revival is a complex, global process that merits extensive analysis. I discuss this process in greater detail in "Islamic Revival Among Secondgeneration Arab Muslims in Chicago: The American Experience and Globalization Intersect," Bulletin of the Royal Institute for Inter-Faith Studies 6 (Autumn/Winter, 2004): 2. This research is supported by a Carnegie Corporation Scholar Award.

80. Alejandro Portes, quoted in Charles Hirschman, "The Role of Religion in the Origins and Adaptation of Immigrant Groups in the United States," paper presented at Princeton University conference on "Conceptual and Methodological Developments in the Study of International Migration” 23-25 May 2003. 